\title{
OPTIMASI DAN PEMEKATAN LIPASE Bacillus halodurans CM1
}

\section{OPTIMIZATION AND CONCENTRATION OF LIPASE FROM Bacillus halodurans CM1}

\author{
Arina Aisyah ${ }^{1}$, Wibowo Mangunwardoyo ${ }^{2}$, Trismilah $^{3}$, Dadang Suhendar ${ }^{3}$ \\ ${ }^{I}$ Program Pascasarjana Biologi, Departemen Biologi, Fakultas Matematika dan Ilmu Pengetahuan Alam, Universitas \\ Indonesia, Depok 16424 \\ ${ }^{2}$ Departemen Biologi, Fakultas Matematika dan Ilmu Pengetahuan Alam, Universitas Indonesia, Depok 16424 \\ ${ }^{3}$ Laboratorium Pengembangan Teknologi Industri Agro dan Biomedika, Badan Pengkajian dan Penerapan Teknologi, \\ Serpong 15314 \\ *Coresponding author: arinaisyah@ @otmail.com
}

Naskah Diterima: 17 Februari 2017; Direvisi: 12 Mei 2017; Disetujui: 02 Juni 2017

\begin{abstract}
Abstrak
Lipase diketahui memiliki peranan penting dalam bidang industri. Produksi lipase dapat dihasilkan oleh kapang, khamir, dan bakteri. Penelitian bertujuan untuk meningkatkan aktivitas lipase yang dihasilkan oleh Bacillus halodurans CM1. Aktivitas lipase dapat ditingkatkan dengan optimasi komposisi media, mutasi bakteri dengan radiasi gamma dan $N$-methyl- $N$ '-nitro- $N$-nitrosoguanidine (NTG). Enzim yang dihasilkan dipekatkan dengan metode stirred-cell ultrafiltration (UF)ammonium sulfat dan UF-Polyethylene glycol (PEG). Uji aktivitas dilakukan pada tujuh media yang berbeda untuk mendapatkan media produksi. Delapan variabel komposisi media dioptimasi dengan rancangan Plackett-Burman. Bakteri dimutasi dengan radiasi gamma dosis $0,1-0,4 \mathrm{kGy}$ dan NTG $0,05-0,15 \mathrm{mg} / \mathrm{mL}$ dengan waktu inkubasi 1-3 jam. Hasil penelitian menunjukkan bahwa media produksi yang digunakan berdasarkan optimasi media dan komposisi media Plackett-Burman adalah media dasar Bora \& Bora yang mengandung 0,5\% palm oil (PO) dan $0,09 \% \mathrm{CaCl}_{2}$. Aktivitas lipase optimal diproduksi oleh bakteri hasil mutasi dengan NTG $0,1 \mathrm{mg} / \mathrm{mL}$ yang diinkubasi selama 3 jam. Pemekatan enzim UF-ammonium sulfat dan UF-PEG mampu meningkatkan aktivitas enzim lipase sebesar $18,44 \%$.
\end{abstract}

Kata kunci: Bacillus halodurans; lipase; mutasi; optimasi; pemekatan enzim

\begin{abstract}
Lipase is known to have an important role in the industrial field. Lipase can be produced by molds, yeasts, and bacteria. The research aimed to increase the activity of lipase produced by Bacillus halodurans CM1. Lipase activity can be improved by optimization of the composition of the media, the mutation of bacteria with gamma radiation and $N$-methyl-N'-nitro-N-nitrosoguanidine (NTG). The enzyme was concentrated by stirred-cell ultrafiltration method (UF)-ammonium sulfate and UF-Polyethylene glycol (PEG). The activity test was performed on seven different media to get production media. The eight variables of the media composition were optimized by PlackettBurman design. The bacteria were subject to mutation by using 0.1-0.4 kGy dose of gamma radiation and $0.05-0.15 \mathrm{mg} / \mathrm{mL}$ NTG with incubation time for 1-3 hours. The results showed that the production media used based on optimization and composition of Plackett-Burman media was Bora Bora medium that containing 0.5\% palm oil (PO) and 0.09\% CaCl $\mathrm{Cl}_{2}$. Pptimum lipase activity

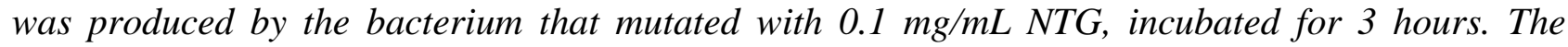
concentrated by UF-ammonium sulfate and UF-PEG could increase the lipase activity by $18.44 \%$.
\end{abstract}

Keywords: Bacillus halodurans; enzyme concentration; lipase; mutation; optimization

Permalink/DOI: http//:dx.doi.org/10.15408/kauniyah.v10i2.4908 


\section{PENDAHULUAN}

Lipase (EC 3.1.1.3) merupakan enzim hidrolisis yang mengkatalis hidrolisis triacylglycerol menjadi glycerol dan asam lemak dengan melepaskan gugus asam dan alkohol, serta mengkatalis reaksi seperti esterifikasi dan transesterifikasi (Damaso et al., 2008; Mala \& Takeuchi, 2008). Kemampuan tersebut menyebabkan lipase memilki peranan penting dalam bidang industri dan proses kimia organik, seperti industri makanan, kimia, farmasi, kertas, kosmetik, agrokimia, dan deterjen (Anbu et al., 2013).

Lipase diproduksi oleh banyak mikroorganisme, seperti bakteri, kapang, dan khamir (Devi et al., 2012). Sharma et al. (2001) mengatakan bahwa bakteri dari genus Bacillus mampu menghasilkan lipase. Berdasarkan penelitian pendahuluan yang dilakukan oleh tim BPP Teknologi, Bacillus halodurans CM1, diisolasi dari sumber air panas, Cimanggu, Jawa Barat berpotensi dalam menghasilkan enzim ekstraselular, seperti xilanase dan protease (Ulfah et al., 2011). Penelitian mengenai produksi dan optimasi lipase sudah banyak dilakukan pada bakteri Bacillus, namun pada $B$. halodurans belum diketahui kemampuannya dalam menghasilkan lipase.

Produksi lipase oleh mikroorganisme dipengaruhi oleh beberapa faktor, seperti sumber karbon dan nitrogen, $\mathrm{pH}$, serta suhu. Faktor-faktor tersebut perlu diatur, sehingga dapat menghasilkan kondisi optimum untuk produksi lipase. Peningkatan aktivitas lipase dapat ditingkatkan dengan mengoptimasi komposisi dan kondisi medium menggunakan suatu metode statistik. Plackett-Burman merupakan salah satu bagian dari metode permukaan respon (RSM) yang dapat menentukan kondisi optimum menggunakan analisis statistik, di mana tiap variabel yang digunakan terdiri dari rentang nilai terendah dan nilai tertinggi dengan mengandung respon optimal (Liu et al. 2012). Abdel-Fattah et al. (2002) menggunakan lima belas variabel faktor dalam rancangan Plackett-Burman untuk produksi lipase dari Bacillus sp. Rancangan Plackett-Burman diharapkan mampu membantu meningkatkan aktivitas lipase.

Selain dengan optimasi komposisi dan kondisi media, peningkatan aktivitas lipase juga dapat dilakukan dengan meningkatkan kemampuan strain bakteri dalam menghasilkan produk (Vu et al., 2009; Xu et al., 2011; Sharma \& Singh, 2012; Shahbazi et al., 2014). $\mathrm{Vu}$ et al. (2011) melakukan mutasi dengan radiasi gamma dan $N$-methyl-N'-nitro- $N$ nitrosoguanidine (NTG) untuk meningkatkan produksi selulase. Mutasi juga dapat diprediksi dengan metode bioinformatika, seperti yang dilakukan oleh Tambunan et al. (2014) terhadap Candida antartica yang menghasilkan lipase.

Penelitian yang dilakukan bertujuan untuk meningkatkan aktivitas lipase yang dihasilkan oleh B. halodurans CM1. Peningkatan aktivitas dilakukan dengan mengoptimasi komposisi dan kondisi media produksi enzim serta meningkatkan kemampuan bakteri dalam menghasilkan enzim dengan mutasi. Pemekatan enzim dilakukan dengan pendekatan filtrasi dan pengendapan.

\section{MATERIAL DAN METODE Bahan}

Bacillus halodurans CM1 koleksi LAPTIAB BPP Teknologi, perangkat radiasi gamma (BATAN), N-methyl-N'-nitro- $N$ nitrosoguanidine (NTG), ammonium sulfat, dan polyethylene glycol (PEG).

\section{Cara Kerja \\ Penentuan Media Produksi}

Bakteri dibiakkan dalam medium LB cair pH 9 dalam erlenmeyer $250 \mathrm{~mL}$, volume kerja $50 \mathrm{~mL}$ untuk membuat seed culture. Seed culture diberi agitasi $200 \mathrm{rpm}$, suhu $50{ }^{\circ} \mathrm{C}$ dan diinkubasi selama 18-24 jam. Seed culture dimasukkan sebanyak $10 \%(\mathrm{v} / \mathrm{v})$ dari total medium LB starter $\mathrm{pH} 9$ ke dalam medium starter. Biakan diinkubasi pada suhu $50{ }^{\circ} \mathrm{C}$ dengan agitasi $200 \mathrm{rpm}$, sampai optical density (OD) terukur $0,6-0,8$ dalam spektrofotometer dengan panjang gelombang $600 \mathrm{~nm}$. Ketika OD biakan sudah mencapai rentang $0,6-0,8$ biakan dimasukkan ke dalam masing-masing media produksi sebanyak $10 \%(\mathrm{v} / \mathrm{v})$ dari total volume medium produksi.

Media produksi yang digunakan berdasarkan media Mamo et al. (2006) dan Bora \& Bora (2012) dengan modifikasi. Sumber N (pepton) disubstitusi dengan tepung 
ikan. Sumber C (minyak) yang digunakan adalah sunflower oil (SFO), palm oil (PO), dan crude palm oil (CPO). Media dasar Mamo, yaitu tepung ikan $0,92 \%, \mathrm{NaCl} 0,20 \%, \mathrm{Na}_{2} \mathrm{CO}_{3}$ $1 \%, \mathrm{MgSO}_{4} \cdot 7 \mathrm{H}_{2} \mathrm{O} 0,01 \%, \mathrm{KH}_{2} \mathrm{PO}_{4} 0,10 \%$ dan
$\mathrm{CaCl}_{2} .2 \mathrm{H}_{2} \mathrm{O} 0,01 \%$ pada $\mathrm{pH}$ 11. Media dasar Bora \& Bora mengandung tepung ikan 0,92\%, $\mathrm{NaCl} 0,02 \%, \mathrm{Na}_{2} \mathrm{CO}_{3} 0,10 \%, \mathrm{MgSO}_{4} \cdot 7 \mathrm{H}_{2} \mathrm{O}$ $0,04 \%, \mathrm{KH}_{2} \mathrm{PO}_{4} 0,30 \%$ pada $\mathrm{pH}$ 9. Media yang digunakan dapat dilihat pada Tabel 1.

Tabel 1. Media produksi lipase

\begin{tabular}{ccccc}
\hline \multirow{2}{*}{ No. } & \multirow{2}{*}{ Media } & \multicolumn{3}{c}{ Komposisi (\%) } \\
\cline { 3 - 5 } & Mamo & dasar & Sumber C & $\mathrm{CaCl}_{2}$ \\
\hline 1 & Mamo & + & - & - \\
2 & Bora \& Bora & + & PO 0,50 & - \\
3 & Bora \& Bora & + & - & - \\
4 & Bora \& Bora & + & SFO 0,50 & - \\
5 & Bora \& Bora & + & PO 0,50 & - \\
6 & Bora \& Bora & + & PO 0,50 & 0,09 \\
7 & & & & 0,01 \\
\hline
\end{tabular}

Biakan kocok medium produksi diinkubasi dalam Erlenmeyer $500 \mathrm{~mL}$ dengan volume kerja $100 \mathrm{~mL}$, agitasi $200 \mathrm{rpm}$ pada suhu $50^{\circ} \mathrm{C}$ selama 20 jam. Media kemudian dimasukkan dalam falcon dan disentrifugasi $3800 \mathrm{rpm}$ selama 30 menit pada suhu $4{ }^{\circ} \mathrm{C}$. Supernatan diambil sebagai enzim kasar.

\section{Aktivitas Lipase}

Uji aktivitas lipase dilakukan berdasarkan metode titrasi (Li et al., 2014) Substrat dibuat dengan komposisi minyak zaitun $25 \%$, poly vinyl alcohol (PVA) 1,5\%, dan air reverse osmosis (RO) yang dihomogenkan dengan homogenizer. Substrat sebanyak $5 \mathrm{~mL}$ diambil dan ditambahkan dengan larutan penyangga tris- $\mathrm{HCl} 0,05 \mathrm{M} \mathrm{pH}$ 8 sebanyak $4 \mathrm{~mL}$, lalu ditambahkan enzim sebanyak $1 \mathrm{~mL}$. Inkubasi dilakukan pada suhu $37^{\circ} \mathrm{C}$, $150 \mathrm{rpm}$, selama 20 menit. Setelah inkubasi, sampel ditambahkan dengan $5 \mathrm{~mL}$ metanol, lalu dititrasi dengan $\mathrm{NaOH} 0,05 \mathrm{M}$. Aktivitas enzim $(\mathrm{U} / \mathrm{mL})$ dihitung berdasarkan rumus berikut:

Aktivitas enzim $(\mathrm{U} / \mathrm{mL})=\frac{(\text { volume titran sample }- \text { kontrol }) \times 1000 \mathrm{x} M}{\text { lamainkubasi }}$

\section{Optimasi Komposisi Media}

Optimasi komposisi media produksi dirancang dengan menggunakan program Design Expert v.7.1.5. Plackett-Burman digunakan sebagai screening factor dengan delapan variabel yang merupakan komposisi dan kondisi media terpilih, yaitu konsentrasi $\mathrm{PO}$, tepung ikan, $\mathrm{NaCl}, \mathrm{Na}_{2} \mathrm{CO}_{3}, \mathrm{MgSO}_{4}$, $\mathrm{KH}_{2} \mathrm{PO}_{4}, \mathrm{CaCl}_{2}$, dan $\mathrm{pH}$. Tiap variabel terdiri dari dua level, yaitu level bawah (-) dan level atas (+). Rancangan percobaan dapat dilihat pada Tabel 2. dan Tabel 3.

Tabel 2.Variabel bebas dan rentang level

\begin{tabular}{clcc}
\hline \multirow{2}{*}{ No. } & & \multicolumn{2}{c}{ Level } \\
\cline { 3 - 4 } & & $(-)$ & $(+)$ \\
\hline 1 & $\mathrm{PO}$ & 0,30 & 1,00 \\
2 & Tepung ikan & 0,70 & 1,40 \\
3 & $\mathrm{NaCl}$ & 0,01 & 0,05 \\
4 & $\mathrm{Na}_{2} \mathrm{CO}_{3}$ & 0,08 & 0,12 \\
5 & $\mathrm{MgSO}_{4}$ & 0,02 & 0,06 \\
6 & $\mathrm{KH}_{2} \mathrm{PO}_{4}$ & 0,20 & 0,50 \\
7 & $\mathrm{CaCl}_{2}$ & 0,07 & 0,14 \\
8 & $\mathrm{pH}$ & 9 & 10 \\
\hline
\end{tabular}


Tabel 3. Rancangan percobaan Plackett-Burman

\begin{tabular}{|c|c|c|c|c|c|c|c|c|}
\hline Run & $\begin{array}{c}\text { Faktor } 1 \\
\text { A:PO } \\
\%\end{array}$ & $\begin{array}{c}\text { Faktor } 2 \\
\text { B:T.ikan } \\
\%\end{array}$ & $\begin{array}{c}\text { Faktor } 3 \\
\mathrm{C}: \mathrm{NaCl} \\
\%\end{array}$ & $\begin{array}{c}\text { Faktor } 4 \\
\mathrm{D}: \mathrm{Na}_{2} \mathrm{CO}_{3} \\
\%\end{array}$ & $\begin{array}{c}\text { Faktor } 5 \\
\text { E:MgSO } \\
\% \\
\end{array}$ & $\begin{array}{c}\text { Faktor } 6 \\
\mathrm{~F}: \mathrm{KH}_{2} \mathrm{PO}_{4} \\
\%\end{array}$ & $\begin{array}{c}\text { Faktor } 7 \\
\mathrm{G}: \mathrm{CaCl}_{2} \\
\%\end{array}$ & $\begin{array}{c}\text { Faktor } 8 \\
\text { H:pH }\end{array}$ \\
\hline 1 & 1 & 0,7 & 0,05 & 0,12 & 0,02 & 0,5 & 0,14 & 10 \\
\hline 2 & 1 & 1,4 & 0,05 & 0,08 & 0,02 & 0,2 & 0,14 & 9 \\
\hline 3 & 1 & 1,4 & 0,01 & 0,08 & 0,02 & 0,5 & 0,07 & 10 \\
\hline 4 & 1 & 0,7 & 0,01 & 0,08 & 0,06 & 0,2 & 0,14 & 10 \\
\hline 5 & 0,3 & 0,7 & 0,01 & 0,08 & 0,02 & 0,2 & 0,07 & 9 \\
\hline 6 & 0,3 & 0,7 & 0,01 & 0,12 & 0,02 & 0,5 & 0,14 & 9 \\
\hline 7 & 0,3 & 0,7 & 0,05 & 0,08 & 0,06 & 0,5 & 0,07 & 10 \\
\hline 8 & 1 & 0,7 & 0,05 & 0,12 & 0,06 & 0,2 & 0,07 & 9 \\
\hline 9 & 0,3 & 1,4 & 0,05 & 0,12 & 0,02 & 0,2 & 0,07 & 10 \\
\hline 10 & 1 & 1,4 & 0,01 & 0,12 & 0,06 & 0,5 & 0,07 & 9 \\
\hline 11 & 0,3 & 1,4 & 0,05 & 0,08 & 0,06 & 0,5 & 0,14 & 9 \\
\hline 12 & 0,3 & 1,4 & 0,01 & 0,12 & 0,06 & 0,2 & 0,14 & 10 \\
\hline
\end{tabular}

Produksi dilakukan pada kultur kocok dengan volume $25 \mathrm{~mL}$ dalam erlenmeyer 125 $\mathrm{mL}$ selama 18 jam untuk selanjutnya diuji aktivitas enzim. Data yang didapat selanjutnya akan dianalisis dengan program Design Expert v.7.1.5. Masing-masing data dilihat signifikansinya berdasarkan nilai $\mathrm{F}$ dan $\mathrm{P}$ pada ANOVA (Wibisana et al., 2015).

\section{Mutasi Bacillus halodurans CM1}

Bakteri dimutasi dengan cara diradiasi gamma dan diberi N-methyl-N'-nitro-Nnitrosoguanidine (NTG). Langkah mutasi dengan radiasi gamma adalah bakteri dibiakkan dengan biakan kocok pada media LB pH 9 dengan volume kerja $50 \mathrm{~mL}$ dalam erlenmeyer $250 \mathrm{~mL}$, selama 18-24 jam pada suhu $50^{\circ} \mathrm{C}$, dan agitasi $200 \mathrm{rpm}$. Suspensi bakteri sebanyak $3 \mathrm{~mL}$ selanjutnya diradiasi. Dosis yang digunakan untuk iradiasi, yaitu 0,1 ; 0,2; 0,3; dan 0,4 kGy (Iftikhar et al., 2010; Shahbazi et al., 2014). Uji aktivitas dilakukan terhadap bakteri yang diradiasi.

Konsentrasi NTG yang digunakan untuk mutasi bakteri, yaitu 0,$05 ; 0,1$; dan 0,15 $\mathrm{mg} / \mathrm{mL}$ ( $\mathrm{Vu}$ et al., 2009). Mutasi bakteri dengan NTG terbagi menjadi beberapa tahapan, yaitu tahap pembuatan biakan bakteri, pencucian, dan inkubasi.

Satu koloni bakteri diinokulasikan ke dalam $5 \mathrm{~mL} \mathrm{LB} \mathrm{pH} \mathrm{9,} \mathrm{diinkubasi} \mathrm{18-24} \mathrm{jam}$ pada suhu $50^{\circ} \mathrm{C}$, agitasi $200 \mathrm{rpm}$. Biakan sebanyak masing-masing $1 \mathrm{~mL}$ dimasukkan ke dalam microtube, disentrifugasi $10000 \mathrm{rpm}, 10$ menit, $4^{\circ} \mathrm{C}$. Pelet ditambahkan dengan $1 \mathrm{~mL}$ larutan penyangga tris-maleat (TM), dihomogenisasi. Suspensi kemudian disentrifugasi. Tahapan pencucian tersebut diulangi sebanyak dua kali. Setelah disentrifugasi, pelet ditambahkan $1 \mathrm{~mL}$ larutan penyangga NTG. Suspensi dihomogenisasi, kemudian diinkubasi selama 1 jam. Suspensi disentrifugasi lalu masuk ke tahap pencucian kembali. LB sebanyak $1 \mathrm{~mL}$ ditambahkan pada pelet, dihomegenisasi, lalu diuji aktivitasnya.

Konsentrasi NTG yang telah didapat kemudian digunakan untuk mutasi bakteri, dengan variasi waktu inkubasi. Waktu inkubasi yang digunakan, yaitu 1, 2, dan 3 jam. Metode yang digunakan sama dengan mutasi variasi konsentrasi.

\section{Pemekatan Enzim}

Pemekatan enzim dilakukan dengan metode stirred-cell ultrafiltration (UF), presipitasi ammonium sulfat (AS), dan polyethylene glycol (PEG). Enzim kasar dipekatkan bertingkat dengan UF-AS dan UFPEG. Sampel hasil pemekatan dilihat aktivitasnya.

Enzim kasar sebanyak $200 \mathrm{~mL}$ dimasukkan ke dalam tangki. Perangkat UF dengan membran filter berukuran $30 \mathrm{kDa}$ diletakkan dalam wadah berisi air es, sebelum gas dengan tekanan 30 psi dialirkan. Enzim dalam tangki diberi putaran $100 \mathrm{rpm}$. Sampling 
dilakukan pada enzim kasar sebelum proses UF dan pada pemekatan 10x. Sampel dianalisis untuk mengetahui aktivitas enzim.

Enzim hasil pemekatan dengan UF dipekatkan kembali dengan AS. AS ditambahkan secara perlahan dengan fraksinasi bertingkat $20-80 \%$ ke dalam $10 \mathrm{~mL}$ enzim yang disiapkan dalam gelas beker pada wadah berisi air es sambil diputar di atas magnetic stirer. Enzim diinkubasi selama 1 jam lalu disentrifugasi dalam falcon dengan kecepatan $3800 \mathrm{rpm}$ selama 30 menit. Endapan yang didapat ditambahkan dengan $5 \mathrm{~mL}$ larutan penyangga tris- $\mathrm{HCl} 0,05 \mathrm{M} \mathrm{pH} 7$. Supernatan hasil sentrifugasi dihitung volumenya untuk digunakan untuk fraksi selanjutnya (Borkar et al., 2009).

Selain dilakukan presipitasi AS, enzim hasil pemekatan dengan UF juga dipekatkan kembali dengan PEG. Membran selofan terlebih dahulu disiapkan, kemudian sampel enzim $10 \mathrm{~mL}$ dimasukkan ke dalamnya. Membran sampel diletakkan dalam wadah berisi PEG, kemudian ditaburi kembali dengan PEG sampai seluruh membran tertutupi dan diletakkan dalam kulkas. Enzim dipekatkan dengan faktor pemekatan $2 \mathrm{x}$, selanjutnya diuji aktivitas.

\section{HASIL}

\section{Media Produksi}

Produksi enzim dari B. halodurans CM1 dilakukan pada tujuh media yang berbeda. Media 6 (Bora \& Bora dengan PO 0,50\% dan $\mathrm{CaCl}_{2}$ 0,09\%) menghasilkan aktivitas lipase tertinggi, yaitu $6,47 \mathrm{U} / \mathrm{mL}$. Grafik aktivitas lipase dapat dilihat pada Gambar 1.

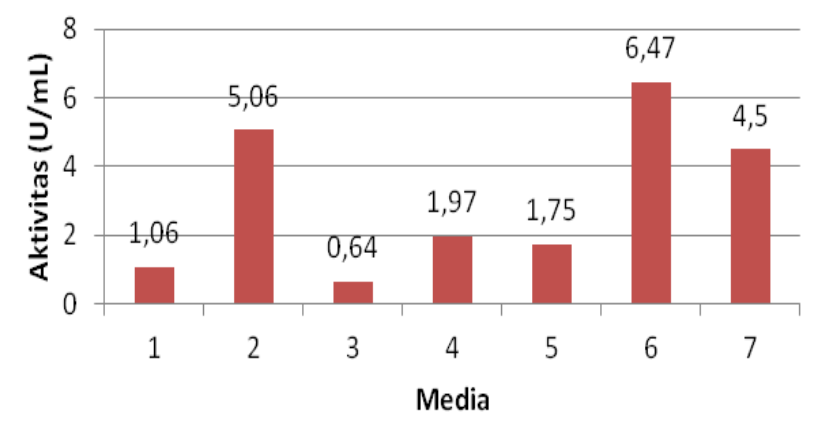

Gambar 1. Aktivitas lipase tertinggi dari tiap media

Tabel 4. Kadar protein bahan dengan metode Lowry

\begin{tabular}{lc}
\hline \multicolumn{1}{c}{ Sampel } & Kadar protein $(\mathrm{mg} / \mathrm{mL})$ \\
\hline Yeast extract & 10,32 \\
Pepton & 11,18 \\
Tepung ikan & 12,18 \\
\hline
\end{tabular}

Kadar protein bahan diujikan saat pra penelitian. Tepung ikan sebagai pengganti pepton menghasilkan kadar protein yang tinggi dibandingkan bahan lainnya. Kadar protein tepung ikan sebesar $12,18 \mathrm{mg} / \mathrm{mL}$.

\section{Rancangan Plackett-Burman}

Respon dari rancangan Plackett-Burman berupa aktivitas enzim. Run 5 memberikan hasil tertinggi dengan kadar PO 0,30\%, tepung ikan $0,70 \%, \mathrm{NaCl} 0,01 \%, \mathrm{Na}_{2} \mathrm{CO}_{3} 0,06 \%$, $\mathrm{MgSO}_{4} 0,02 \%, \mathrm{KH}_{2} \mathrm{PO}_{4} 0,20 \%, \mathrm{CaCl}_{2} 0,07 \%$, dan $\mathrm{pH} 9$ (Tabel 5). Data dari rancangan Plackett-Burman selanjutnya dianalisis dengan ANOVA pada Design Expert. ANOVA dari rancangan Plackett-Burman menunjukkan model bernilai $F$ 0,93 yang berarti bahwa model tidak signifikan terhadap noise (kesalahan). Nilai p (prob > F) juga menunjukkan bahwa model tidak signifikan.

\section{Mutasi Bakteri}

Hasil uji aktivitas berdasarkan Tabel 6 . menunjukkan bahwa dosis 0,4 kGy menghasilkan aktivitas enzim yang paling tinggi dibandingkan dosis lain, sebesar 3,44 $\mathrm{U} / \mathrm{mL}$. Konsentrasi NTG $0,1 \mathrm{mg} / \mathrm{mL}$ (Tabel 7) dengan masa inkubasi 3 jam (Tabel 8) menghasilkan aktivitas lipase tertinggi, yaitu sebesar 5,13 U/mL. 
Tabel 5. Rancangan Plackett-Burman

\begin{tabular}{cccccccccc}
\hline Run & $\begin{array}{c}\mathrm{PO} \\
(\%)\end{array}$ & $\begin{array}{c}\mathrm{T} . \mathrm{ikan} \\
(\%)\end{array}$ & $\begin{array}{c}\mathrm{NaCl} \\
(\%)\end{array}$ & $\begin{array}{c}\mathrm{Na}_{2} \mathrm{CO}_{3} \\
(\%)\end{array}$ & $\begin{array}{c}\mathrm{MgSO}_{4} \\
(\%)\end{array}$ & $\begin{array}{c}\mathrm{KH}_{2} \mathrm{PO}_{4} \\
(\%)\end{array}$ & $\begin{array}{c}\mathrm{CaCl}_{2} \\
(\%)\end{array}$ & $\mathrm{pH}$ & $\begin{array}{c}\text { Aktivitas } \\
(\mathrm{U} / \mathrm{mL})\end{array}$ \\
\hline 1 & 1 & 0,7 & 0,05 & 0,12 & 0,02 & 0,5 & 0,14 & 10 & 1,63 \\
2 & 1 & 1,4 & 0,05 & 0,06 & 0,02 & 0,2 & 0,14 & 9 & 1,28 \\
3 & 1 & 1,4 & 0,01 & 0,06 & 0,02 & 0,5 & 0,07 & 10 & 1,25 \\
4 & 1 & 0,7 & 0,01 & 0,06 & 0,06 & 0,2 & 0,14 & 10 & 1,66 \\
5 & 0,3 & 0,7 & 0,01 & 0,06 & 0,02 & 0,2 & 0,07 & 9 & 1,84 \\
6 & 0,3 & 0,7 & 0,01 & 0,12 & 0,02 & 0,5 & 0,14 & 9 & 1,41 \\
7 & 0,3 & 0,7 & 0,05 & 0,06 & 0,06 & 0,5 & 0,07 & 10 & 1,03 \\
8 & 1 & 0,7 & 0,05 & 0,12 & 0,06 & 0,2 & 0,07 & 9 & 0,75 \\
9 & 0,3 & 1,4 & 0,05 & 0,12 & 0,02 & 0,2 & 0,07 & 10 & 1,44 \\
10 & 1 & 1,4 & 0,01 & 0,12 & 0,06 & 0,5 & 0,07 & 9 & 1,13 \\
11 & 0,3 & 1,4 & 0,05 & 0,06 & 0,06 & 0,5 & 0,14 & 9 & 1,16 \\
12 & 0,3 & 1,4 & 0,01 & 0,12 & 0,06 & 0,2 & 0,14 & 10 & 1,41 \\
\hline
\end{tabular}

Tabel 6. Aktivitas lipase berdasarkan hasil radiasi gamma

\begin{tabular}{cc}
\hline Dosis & Aktivitas $(\mathrm{U} / \mathrm{mL})$ \\
\hline 0,10 & 3,31 \\
0,20 & 3,38 \\
0,30 & 3,22 \\
0,40 & 3,44 \\
\hline
\end{tabular}

Tabel 7. Aktivitas lipase berdasarkan hasil variasi konsentrasi NTG

\begin{tabular}{cc}
\hline Konsentasi $(\mathrm{mg} / \mathrm{mL})$ & Aktivitas $(\mathrm{U} / \mathrm{mL})$ \\
\hline 0,05 & 3,44 \\
0,10 & 3,56 \\
0,15 & 3,63 \\
\hline
\end{tabular}

Tabel 8. Aktivitas lipase berdasarkan hasil variasi lama inkubasi

\begin{tabular}{cc}
\hline Jam & Aktivitas (U/mL) \\
\hline 1 & 4,75 \\
2 & 4,72 \\
3 & 5,13 \\
\hline
\end{tabular}

Tabel 9. Aktifitas enzim hasil pemekatan

\begin{tabular}{cccc}
\hline Sampel & Aktivitas $(\mathrm{U} / \mathrm{mL})$ & Aktivitas Spesifik $(\mathrm{U} / \mathrm{mg})$ & Kenaikan Aktivitas $(\%)$ \\
\hline Enzim Kasar & 2,38 & 9,50 & \\
UF & 2,63 & 8,31 & 10,53 \\
UF-AS & 2,81 & 12,96 & 18,44 \\
UF-PEG & 2,81 & 9,50 & 18,44 \\
\hline
\end{tabular}

\section{Pemekatan Enzim}

Aktivitas enzim mengalami peningkatan setelah dipekatkan dengan UF, yaitu dari 2,38 $\mathrm{U} / \mathrm{mL}$ menjadi 2,63 U/mL. Enzim hasil UF mengalami peningkatan aktivitas ketika dipekatkan kembali dengan ammonium sulfat, yaitu menjadi $2,81 \mathrm{U} / \mathrm{mL}$. Hasil yang sama didapat dari pemekatan enzim hasil UF yang 
dipekatkan kembali dengan PEG. Aktivitas enzim setelah dilakukan pemekatan dengan UF meningkat $10,53 \%$. Aktivitas lipase meningkat sebesar $18,44 \%$ pada hasil pemekatan, baik UF-AS maupun UF-PEG (Tabel 9).

\section{PEMBAHASAN}

\section{Media Produksi}

Aktivitas enzim tertinggi dihasilkan pada media 6 (Bora \& Bora, 2012) dengan PO 0,5\% dan $\mathrm{CaCl}_{2}$ 0,09\% (Gambar 1). PO berfungsi sebagai sumber karbon sekaligus substrat, sedangkan tepung ikan berfungsi sebagai sumber nitrogen. Kebutuhan energi untuk pertumbuhan mikroba dapat dipenuhi oleh adanya sumber karbon, selain dapat digunakan sebagai substrat untuk produksi enzim. Sumber nitrogen berfungsi sebagai penyedia protein dan asam amino untuk menunjang pertumbuhan bakteri dan produksi enzim (Chauhan \& Garlapati, 2013).

PO memberi efek pada aktivitas lipase lebih tinggi dibandingkan dengan SFO dan CPO. Hal ini sedikit berbeda jika dibandingkan dengan penelitian yang dilakukan oleh Bora \& Bora (2012) menggunakan Bacillus sp. terhadap beberapa sumber karbon untuk produksi lipase selama 70 jam menunjukkan SFO menghasilkan aktivitas yang lebih tinggi jika dibandingkan dengan PO. SFO menghasilkan aktivitas sekitar $17 \mathrm{U} / \mathrm{mL}$, sedangkan PO sekitar $5 \mathrm{U} / \mathrm{mL}$.

Pepton diketahui sebagai sumber nitrogen terbaik untuk produksi lipase (Kanwar et al., 2002; Thomas et al., 2003; Gulati et al., 2005). Tepung ikan digunakan sebagai pengganti pepton karena kadar protein tepung ikan ikan sebesar $12,18 \mathrm{mg} / \mathrm{mL}$, sedangkan kadar protein pepton 11,18 mg/mL (Tabel 4).

\section{Rancangan Plackett-Burman}

Hasil analisis yang tidak signifikan kemungkinan disebabkan oleh data yang tidak mendukung hipotesis. Data yang tidak mendukung mungkin disebabkan oleh penentuan rentang level pada tiap variabel kurang lebar karena menurut Demain dan Davies (1999) rentang level pada PlackettBurman harus lebar dan mengandung respon optimal. Penelitian ini mendapatkan hasil analisis yang berbeda dengan penelitian lain yang dilakukan oleh Wibisana et al. (2015) dengan hasil ANOVA yang signifikan pada empat dari tujuh variabel yang dianalisis. Abdel-Fattah et al. (2002) menggunakan lima belas variabel faktor dalam rancangan PlackettBurman untuk produksi lipase dari Bacillus sp.

\section{Mutasi Bakteri}

Berdasarkan Tabel 7, konsentrasi NTG $0,15 \mathrm{mg} / \mathrm{mL}$ merupakan konsentrasi yang memberikan hasil aktivitas terbaik. Namun untuk optimasi mutasi selanjutnya, konsentasi NTG yang digunakan adalah $0,1 \mathrm{mg} / \mathrm{mL}$. Konsentrasi tersebut digunakan berdasarkan literatur $\mathrm{Vu}$ et al. (2011) yang menyatakan bahwa kosentrasi NTG yang dipakai adalah 0,1 $\mathrm{mg} / \mathrm{mL}$. Jika dibandingkan aktivitas pada konsentrasi NTG 0,1 dan $0,15 \mathrm{mg} / \mathrm{mL}$ tidak jauh berbeda, hanya terpaut 0,07 .

Konsentrasi NTG 0,1 digunakan untuk optimasi waktu inkubasi yang digunakan selama mutasi. Tabel 7. menunjukkan bahwa aktivitas lipase terbaik pada waktu inkubasi 3 jam. Waktu inkubasi yang lebih lama, yaitu 3 jam memungkinkan terjadinya mutasi lebih besar (Andreoni et al., 1995). Jika dibandingkan aktivitas lipase hasil mutasi dengan iradiasi gamma dan mutasi dengan NTG, maka terlihat bahwa mutasi dengan NTG lebih baik dalam meningkatkan aktivitas lipase.

\section{Pemekatan Enzim}

Pemekatan enzim kasar dengan UF menggunakan membran milipore berpori 30 $\mathrm{kDa}$ dengan diameter $76 \mathrm{~mm}$. Kondisi tersebut mengindikasikan bahwa enzim lipase yang dipekatkan dengan UF berukuran $>30 \mathrm{kDa}$. Lipase yang dihasilkan oleh bakteri dari genus Bacillus memiliki berat molekul berkisar dari 19-40 kDa (Sangeetha et al., 2010; Shah \& Bhatt, 2012; Rabbani et al., 2015). Enzim kasar dengan aktivitas sebesar 2,38 U/mL dipekatkan 10x, sehingga aktivitasnya menjadi 2,63 U/mL. Enzim hasil pemekatan dengan UF selanjutnya dipekatkan kembali dengan AS dan PEG.

Penambahan konsentrasi garam pada metode AS meningkatkan kelarutan protein sejalan dengan meningkatnya konsentrasi garam (salting in). Ammonium sulfat yang ditambahkan secara terus-menerus akan menyebabkan kelarutan protein menurun (salting out) yang berarti protein hampir sepenuhnya terendapkan (Wingfield, 2001). 
Enzim lipase dipekatkan dengan AS sampai fraksi $20 \%$. Hasil fraksi $20 \%$ dilarutkan dalam larutan penyangga tris- $\mathrm{HCl} 0,05 \mathrm{M} \mathrm{pH} 7$, kemudian didialisis. Aktivitas enzim lipase meningkat dari $2,63 \mathrm{U} / \mathrm{mL}$ menjadi 2,81 $\mathrm{U} / \mathrm{mL}$. Adanya peningkatan aktivitas enzim tersebut, sesuai dengan penelitian yang dilakukan Nurhasanah \& Herasasi (2008) yang menyatakan pemekatan dengan ammonium sulfat mampu meningkatkan aktivitas enzim lipase.

Enzim hasil pemekatan dengan UF juga dipekatkan dengan PEG. Membran dialisis yang digunakan mempunyai ukuran pori 12 kDa, sedangkan PEG berukuran $20 \mathrm{kDa}$. PEG akan menyebabkan molekul pada enzim yang berukuran lebih kecil dari $12 \mathrm{kDa}$ akan tertarik keluar membran, sedangka PEG tidak dapat masuk ke dalam membran karena ukurannya lebih besar dari $20 \mathrm{kDa}$. Aktivitas enzim lipase hasil PEG sebesar 2,81 U/mL. Hasil pemekatan lipase dapat dilihat pada Tabel 9.

\section{KESIMPULAN}

Aktivitas lipase tertinggi $B$. halodurans dihasilkan pada media Bora \& Bora yang mengandung $0,5 \%$ PO dan $0,09 \% \quad \mathrm{CaCl}_{2}$. Mutasi dengan NTG $0,1 \mathrm{mg} / \mathrm{mL}$ inkubasi 3 jam meningkatkan aktivitas lipase paling tinggi dibandingkan dengan sinar gamma. Pemekatan enzim dengan metode UF-AS dan UF-PEG mampu meningkatkan aktivitas enzim dengan nilai sama, sebesar $18,44 \%$.

\section{UCAPAN TERIMA KASIH}

Ucapan terima kasih kepada staf Biokatalis, LAPTIAB, BPPT, Serpong dan pihak-pihak yang telah membantu selama proses penelitian.

\section{REFERENSI}

Abdel-Fattah, Y. R., Soliman, N. A., Gaballa, A. A., Sabry, S. A., \& El-Diwany, A. I. (2002). Lipase production from a novel thermophilic Bacillus sp.: application of Plackett-Burman design for evaluating culture conditions affecting enzyme formation. Acta Microbiologica Polonica, 51(4), 353-366.

Anbu, P., Gopinath, S. C. B., Cihan, A. C., \& Chaulagain, B. P. (2013). Microbial enzymes and their applications in industries and madicine. BioMed Research International, 2013, 1-2.

Andreoni, V., Bernasconi, S., \& Bestetti, G. (1995). Biotransformation of ferulic acid and related compound by mutant strains of Pseudomonas fluorescens. Applied Microbial Biotechnology, 42, 830-835.

Bora, L. \& Bora, M. (2012). Optimization of extracellular thermophilic highly alkaline lipase from thermophilic Bacillus sp. isolated from Hot Spring Arunachal Pradesh, India. Brazilian Journal of Microbiology, 30-42.

Borkar, P. S., Bodade, R. G., Rao, S. R., \& Khobragde, C. N. (2009). Purification and characterization of extracellular lipase from a new strain-Pseudomonas aeruginosa SRT 9. Brazilian Journal of Microbiology, 40, 358-366.

Chauhan, M., \& Garlapati, V. K. (2013). Production and characterization of a halo-, solvent-, thermo-tolerant alkaline lipase by Staphylococcus arlettae JPBW1, isolated from rock salt mine. Applied Biochemistry and Biotechnology, 171, 1429-1443.

Damaso, M. C. T., Passianoto, M. A., de Freitas, S. C., Freire, D. M. G., Lago, R. C. A., \& Couri, S. (2008). Utilization of agroindustrial residues for lipase production by solid-state fermentation. Brazilian Journal of Microbiology, 39, 676-681.

Devi, A. S., Devi, K. C., \& Rajendiran, R. (2012). Optimization of lipase production using Bacillus subtilis by response surface methodology. International Journal of Biological, Veterinary, Agricultural and Food Engineering, 6(9), 164-169.

Gulati, R., Isar, J., Kumar, V., Prasad, A. K., Parmar, V. S., \& Saxena, R. K. (2005). Production of novel alkaline lipase from Fusarium globosum using neem oil and its applications. Pure and Applied Chemistry, 77, 251-262.

Iftikhar, T., Niaz, M., Hussain, Y., Abbas, S. Q., Ashraf, I., \& Zia, M. A. (2010). Improvement of selected strains through gamma irradiation for enhanced lipolytic potential. Pakistan Journal of Botany, 42(4), 2257-2267. 
Kanwar, L., Gogoi, B. K., \& Goswami, P. (2002). Production of Pseudomonas lipase in n-Alkane substrate and its isolation using ammonium sulphate precipitation technique. Bioresouce Technology, 84, 207-211.

Li Xiao-Lu, Zhang Wen-Hui, Wang YingDong, Dai Yu-Jie, Zhang Hui-Tu, Wang Yue, Wang Hai-Kuan, \& Lu Fu-Ping. (2014). A high-detergent-performance, cold-adapted lipase from Pseudomonas stutzeri PS59 suitable for detergent formulation. Journal of Molecular Catalysis B: Enzymatic, 102, 16-24.

Liu Xiangyang, Ren Biao, Gao Hong, Liu Mei, Dai Huanqin, Song Fuhang, Yu Zhenyan, Wang Shujin, Hu Jiangchun, Kokare, C. R., \& Zhang Lixin. (2012). Optimization for the production of surfactin with a new synergistic antifungal activity. Plos One, 7(5), 1-9

Mala, J. G. S. \& Takeuchi, S. (2008). Understanding structural feature of mikrobial lipases-An Overview. Analytical Chemistry Insights, 3, 9-19.

Mamo, G., Rajni, H. K., \& Mattiason, B. (2006). A thermostable alkaline active endo- $\beta 1-4$ xylanase from Bacillus halodurans S7: purification and characterization. Enzyme and Microbial Technology, 39(7), 1492-1498.

Nurhasanah \& Herasari, D. (2008). Pemurnian enzim lipase dari bakteri lokal dan aplikasinya dalam reaksi esterifikasi (Prosiding). Seminar Nasional Sains dan Teknologi-II, 17-18 November. Universitas Lampung, Bandar Lampung.

Rabbani, M., Shafiee, F., Shayegh, Z., Sadeghi, H. M. M., Shariat, Z. S., Etemadifar, Z., \& Moazen, F. (2015). Isolation and characterization of a new thermoalkalophilic lipase from soil bacteria. Iranian Journal of Pharmaceutical Research, 14(3), 901906.

Sangeetha, R., Geetha, A., \& Arulpandi, I. (2010). Concomitant production of protease and lipase by Bacillus licheniformis VSG1: production, purification and characterization. Brazilian Journal of Microbiology, 41, 179-185.
Shah, K. R. \& Bhatt, S. A. (2012). Purification and characterization of lipase from Bacillus subtilis Pa2. Journal of Biochemical and Technology, 3(3), 292295.

Shahbazi, S., Ispareh, K., Karimi, M., Askari, H., \& Ebrahimi, M. A. (2014). Gamma and UV radiation induced mutagenesis in Trichoderma reesei to enhance cellulases anzyme activity. International Journal of Farming and Allied Science, 3(5), 543554.

Sharma, R., Chisti, Y., \& Banerjee, U. C. (2001). Production, purification, characterization, and applications of lipases. Biotechnology Advances, 19, 627-662.

Sharma, V. \& Singh, P. K. (2012). Strain improvement of Bacillus coagulans and Geobacillus strearothermophilus for enhanced thermostable cellulase production and the effect of different metal ions on cellulase activity. International Journal of Engineering Science and Technology, 4(11), 47044709.

Tambunan, U. S. F., Randy, A., \& Parikesit, A. A. (2014). Design of Candida antartica lipase B thermostability improvement by introducing extra disulfide bond into the enzyme. OnLine Journal of Biological Sciences, 14 (2), 108-118.

Thomas, A., Manoj, M. K., Valsa, A., Mohan, S., \& Manjula, R. (2003). Optimization of growth condition for the production of extra cellular lipase by Bacillus mycoides. Indian Jounal of Microbiology, 43, 67-69.

Ulfah, M., Helianti, I., Wahyuntari, B., \& Nurhayati, N. (2011). Characterization of new thermoalkalophilic xylanaseproducing bacterial strain isolated from Cimanggu Hots Spring, West Java, Indonesia. Microbiology Indonesia, 5(3), 139-143.

Vu, V. H., Pham, T. A., \& Kim, K. (2009). Fungal strain improvement for cellulase production using repeated and sequential mutagenesis. Mycobiology, 37(4), 267271. 
Vu, V. H., Pham, T. A., \& Kim, K. (2011). Improvement of fungal cellulase production by mutation and optimization of solid state fermentation. Mycobiology, 39(1), 20-25.

Wibisana, A., Sumaryono, W., Sudiro, T. M., \& Sudarmono, P. P. (2015). Optimization of surfactin production by Bacillus amyloliquefaciens MD4-12 using response surface methodology. Microbiology Indonesia, 9(3), 120-128.
Wingfield, P. T. (2001). Protein precipitation using ammonium sulphate. Current Protocols in Protein Science, 84, A.3F 19.

Xu, H., Jia, S., \& Liu, J. (2011). Development of mutant strain of Bacillus subtilis showing enhanced production of acetoin. African Journal of Biotechnology, 10(5), 779-788. 